\title{
An Archaeological and Historical Survey of Walnut Creek, Seguin, Texas
}

James E. Ivey

Cristi Assad

Erwin Roemer

Jack D. Eaton

Follow this and additional works at: https://scholarworks.sfasu.edu/ita

Part of the American Material Culture Commons, Archaeological Anthropology Commons, Environmental Studies Commons, Other American Studies Commons, Other Arts and Humanities Commons, Other History of Art, Architecture, and Archaeology Commons, and the United States History Commons

Tell us how this article helped you.

This Article is brought to you for free and open access by the Center for Regional Heritage Research at SFA ScholarWorks. It has been accepted for inclusion in Index of Texas Archaeology: Open Access Gray Literature from the Lone Star State by an authorized editor of SFA ScholarWorks. For more information, please contact cdsscholarworks@sfasu.edu. 
An Archaeological and Historical Survey of Walnut Creek, Seguin, Texas

Creative Commons License

(C) $(1) \Theta$

This work is licensed under a Creative Commons Attribution-NonCommercial 4.0 International License 


\title{
AN ARCHAEOLOGICAL AND HISTORICAL SURVEY
}

$$
\text { OF WALNUT CREEK, SEGUIN, TEXAS }
$$

\author{
James E. Ivey, Cristi Assad, Erwin Roemer \\ and Jack D. Eaton
}

Center for Árchaeological Research

The University of Texas at San Antonio

Archaeological Survey Report, No. 30 
AN ARCHAEOLOGICAL AND HISTORICAL SURVEY

OF WALNUT CREEK, SEGUIN, TEXAS

James E. Ivey, Cristi Assad, Erwin Roemer

and Jack D. Eaton

Center for Archaeological Research

The University of Texas at San Antonio

Archaeological Survey Report, No. 30

1977 
TABLE OF CONTENTS

PAGE

Preface ......................... $i i$

PART I： HISTORICAL SURVE. ............. 1

Historical Outline................

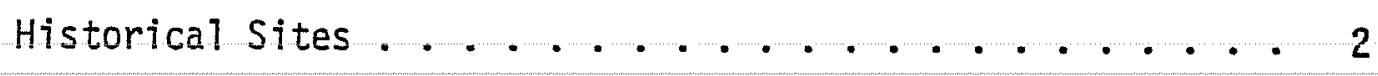

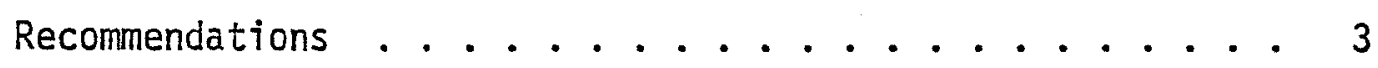

References Cited .................. 4

PART II: ARCHAEOLOGICAL SURVEY ............ 6

Field Procedures and Results............ 6

Concluding Comments ............... 7

\section{ILLUSTRATION}

FIGURE

PAGE

1. Location of Historic Houses on Walnut Branch Creek Noted During UTSA Survey. . . . . . . . . 5 


\section{PREFACE}

During March 1977, the Center for Archaeological Research conducted archaeological and historical surveys of Walnut Creek at Seguin, Texas.

The surveys were performed under contract with Hallenberger, Galindo and Associates, Consulting Engineers. This engineering firm, in turn, has been contracted by the U.S. Corps of Engineers to do a study of proposed flood control developments along Walnut Creek in anticipation of the projected 50-year flood cycle. The archaeological and historical surveys of Walnut Creek were part of a larger study to assess the environmental impact of the area by the proposed flood control developments.

This report, which describes the surveys made along walnut Creek, is presented in two parts: Part I deals with the historical survey and is written by James E. Ivey; Part II covers the archaeological survey done by Cristi Assad and Erwin Roemer.

The results of these surveys and suggested recommendations are presented herein.

Jack D. Eaton

Assistant Director 


\title{
PART I: HISTORICAL SURVEY
}

\author{
James E. Ivey
}

\section{Historical Outline}

The land upon which Seguin now stands originally formed part of a league granted to Humphries Branch, a colonist under Empresario Green DeWitt. The league was granted to Branch by the actions of DeWitt and land commissioner Jose Antonio Navarro on November 20, 1831 (G.L.0.S.A.:v.13, 589).

Branch made a brief attempt to live on and farm the land, but in 1834 the natural difficulties of the country, the rise in Indian animosity and the increasingly difficult political situation all combined to convince him to withdraw from the colony (Fitzsimon 1938:6). On December 31, 1834, he sold the south half of his league to Joseph S. Martin, and the remainder to Thomas R. Miller (G.C.C.R.:GT 384, 74).

Local tradition says that a company of Texas Rangers under the command of Captain Jack Hays was stationed on Walnut Creek immediately after the Texas Revolution, and that an early adobe structure which stood on the banks of the creek had been their "Ranger Station" (C.C.n.d.:1). Other traditions tel1 of their horse shed having been located where the present "Captain Hall House" now stands (C.C.n.d.:1). Many of the activities of the Texas Rangers in the period immediately following the Revolution are poorly recorded, and there may be some truth to these traditions.

In spite of the traditions there is no record of land transfers to the Texas Rangers or any other group or person between December 1834, when Branch sold to Martin, and August 12, 1838, when Martin entered into an agreement with James Campbe11, Arthur Swift and Matthew Caldwe11, all of the town of Gonzales, to establish a town on the north bank of the Guadalupe River on Martin's land. On that date the four major organizers and all others interested in purchasing property in the proposed town assembled in Gonzales, officially announced their intent, and stated the rules under which shares to the town would be sold, including costs and residence requirements; and the 44 shares to the town were sold. Joseph Martin kept 11 shares, the other three organizers had one each, and the 30 remaining were sold to interested persons present (G.C.C.R.: Ams 107).

The next meeting was held on the town site on September 22, 1838. At this meeting the town was named Walnut Springs, and the land was distributed among the shareholders according to the drawing of lots (G.C.C.R.:Ams 1).

By the time of the town meeting of February 25, 1839, a majority of the shareholders was dissatisfied with the name "Walnut Springs" and voted to rename the town. The names "Tuscumbia" and "Seguin" (in honor of Col. Juan N. Seguin of Revolution fame) were suggested. "Seguin" won by a vote of 18 to 7

(G.C.C.R.:Ams 65). 
Construction began on town buildings, and by 1840 there were enough people in the area to warrant the inclusion of Seguin in the postal service between San Antonio and Austin (Fitzsimon 1938:12).

The series of raids, reprisals, and political maneuverings which culminated in the annexation of Texas to the United States in 1845 and the Mexican War of 1846-1849 frequently involved the people of Seguin, as did the Civil War a decade and a half later. In the meantime the town continued to grow. The population of the town in 1850 is estimated at about 700, and a grist mi17, sawmi11, and two cotton gins were in operation (Fitzsimon 1938:15).

In 1853 the town and a neighboring village established in 1847, Guadalupe City, were incorporated as one unit. In the same year the first newspaper in Seguin was established, the "Texas Mercury." The first major drive of cattle from the surrounding county was made to California in 1854, and the town population reached 986 (Fitzsimon 1938:16-21).

The Galveston, Harrisburg and San Antonio Railway reached Seguin in 1876, effectively ending the "Texas Frontier" period for the city.

Historical Sites

The earliest period of settlement in Seguin has yet to be carefully studied, and it was beyond the scope of the present survey to attempt such a study.

Available information, however, indicates that the earliest habitations in the Seguin area were the Humphries Branch house, buitt in 1833 and abandoned in 1834; the house of "French" Smith, built around the same time (there is no deed record to support this tradition, although Smith later became a landowner in Seguin); and the house of the James Milford Day family, a small adobe near Walnut Springs, again unattested by any deed of purchase (Fitzsimon 1938: 6-7). Finally, there is the "Ranger Station" on Walnut Creek. This structure, supposedly built in about 1825 (C.C.n.d.:1), was a small adobe with stone reinforcing, and was originally the home of James Milford Day. In fact, it appears that this is the same Day house mentioned above. The building is no longer standing, having been bulldozed some years ago, but the lot on which it stood was originally granted to shareholder M. P. Woodhouse (G.C.C.R.:Ams 45). Shareholder James M. Day acquired the lot adjacent to this structure on the north (G.C.C.R.:Ams 40). This implies that the "Ranger Station" which iong stood on the southeast corner of Court and Guadalupe Streets was not the house of Texas Ranger James M. Day, but was instead the house of M. P. Woodhouse, built circa 7840 and later confused with the house of Day, known to have stood in the same immediate area.

Other, somewhat more recent structures still standing along Walnut Creek are: (1) the Goodrich School behind 609 South Goodrich (V.F.n.d.:6), built after 1850 of blocks of a material known as "limecrete" (an early predecessor of modern concrete invented by a local chemist, Dr. Richard Parks, in the 1840s). The Goodrich School is one of the few surviving structures of this construction in Seguin today; (2) the "Captain J. Boyd Hall House," a relatively recent house at the intersection of Travis and Nolte Streets which encloses the structure of the original Hall house, built in the 1840s or 1850s. and claimed to be the first house built in the town of Seguin (C.C.n.d.:1); (3) the "Holms House," 
behind 221 West Washington Street, about which little information is available. The structure itself, seen from a distance, could date from 1850 to 1900; the present owner was reluctant to let the author examine the place in any detail; and (4) the Sebastopol (Zorn) House, which is located on Walnut Branch Creek, and is a structure of particular interest.

The Sebastopol House, also called Zorn House, is located near the corner of West Court and North Erkel in Seguin. It is an unusual building in plan and construction, and incorporates architectural features described as Greek Revival. The structure is one-story with a flat roof and built on a partially raised basement. The main story is $T$-shaped with a wide porch surrounding the sten of the $T$. Eight porch columns, squared with molded bases and capitals, support a flat roof with parapet sides which is said to have been lined to form a water reservoir designed to serve as insulation and keep the house cool in the summers. The basic construction of the house is poured concrete, actually the "Timecrete" invented, as noted on page 2, by Dr. Parks (Texas Historical. Commission 1976).

The house was constructed around 1852 by Colonel J. W. Young and was named Sebastopol for the Russian naval base famous during the Crimean War.

One of the subsequent owners of the house was Joseph Zorn, founder of the town of Zorn, who lived there giving the structure its second name.

In 1964 Sebastopol House was designated a Texas Historical Landmark and was subsequently listed on the National Register of Historic Places. Currently the Texas Parks and Wildlife Department owns the house and plans to operate it as a State Historic Structure (National Park Service 1970).

\section{Recommendations}

Of the buildings and sites mentioned above, the Branch and Smith houses are unlocated, and the Holms and Hall houses are active habitations and probably, because of their locations, would be in little danger of destruction by the proposed flood control work discussed in the Preface.

The Goodrich School is behind an active habitation, but shows signs of neglect. Any contemplated earthmoving in this area should make allowances for this structure.

The "Ranger Station" is no longer standing, but the foundations and their associated artifacts and stratigraphy are probably relatively undisturbed, and very likely contain a valuable record of the first days of settlement in Seguin, a record not obstructed or partially destroyed by later buildings as has happened in the case of most other sites in the city. Any planned changes to Walnut Creek involving this tract of land (originally Block 21, lot 1) should either avoid this site or should allow for its excavation.

The Sebastopol House sits on property which extends to the Walnut Branch Creek. Built upon the sloping creek terrace, the rear of the house is some 100 feet or so from the creek, but at an elevation only a few feet above the channel. Although the house is not expected to be directly affected by proposed channel 
modifications in that area of the creek, there could be indirect affects due to proximity and this should be considered in planning channel improvements. We would recommend that a box culvert be installed in the area of the Sebastopol property to control possible stream overflow which would affect the rear of the house (Fig. 1).

\section{REFERENCES CITED}

Chamber of Commerce (C.C.)

n.d. This is an undated, anonymous handout available in the office of the Seguin Chamber of Commerce. It is an edited version of a short guide to historical places in Seguin available in the Public Library (see Vertical Files, below).

G.L.O.S.A.

General Land Office, Spanish Archives. Various dates.

G.C.C.R.

Guadalupe County Clerk's Records. (Note: "Ams" is "deed book A, manuscript copy," and contains a copy of the "Book of Seguin," a record of the acts and transfers which founded the town.

Pagination is uncertain.) Various dates.

Fitzsimon, Laurence $J$.

1938 History of Seguin. C. H. Jackson Directory Company, San Antonio.

Texas Historical Commission

1976 The National Register of Historic Places in Texas, 1968-1975. Austin.

National Park Service

1970 National Register of Historic Places Inventory - Nomination Form. Y.F. 


\title{
PART II: ARCHAEOLOGICAL SURVEY
}

\author{
Cristi Assad and Erwin Roemer
}

\section{Field Procedures and Results}

The survey team of Assad and Roemer initiated the survey of Walnut Creek by moving south from the Southern Pacific Railroad tracks (Fig. 1). One person checked the creek bank side, and the other examined the area above the bank (extending from 1 to $25 \mathrm{~m}$ depending on adjoining private property). The eastern side was walked to West Court Street and the return was made on the western side of the creek. This covered the upper half of the drainage and very little prehistoric evidence was found. The cultivated fields near the railroad were barren of artifacts.

Where Matamoros Street passes near the creek a chert flake was found on the north bank, near a residential backyard. This area of the creek marks the beginning of urban Seguin, typical for the lower drainage to the Guadalupe except that here the vegetation is less dense and the water course is reduced to that of a small low ditch. Another chert flake was found on the western creek side just south of Kingsbury Street (Highway 90). This is in an area that seems to have had some landmoving activity, and piles of earth and rubble are found in the area.

The only upper creek area of thick vegetation and relative seclusion is between the Vaughan Avenue and William Street creek crossings. This section has very abundant plant life, including oaks, bramble vines, white brush, mesquite, cane, thick grasses, and many species of low shrubs. The vegetation extends an average of $30 \mathrm{~m}$ on either side of Walnut Creek along this stretch, blending into residential backyards.

Approximately $40 \mathrm{~m}$ east of Vaughan Street on the northern creek side two chert flakes were found apparently eroding out of the bank. A chert core was noted in the drainage bottom a few meters downstream. This may be the remnant of an eroded archaeological site, but no in situ evidence was found in or above the creek bank. This stretch of Walnut Creek seemed most promising but nothing else was found until the thicket ended near william Street where a few flakes were found on both banks in a cleared area just west of that street. Prehistoric evidence may be within the thicket but is not presentiy exposed in the cut banks or in the extremely thick vegetation.

Between William Street and West Court Street no archaeological evidence was seen This stretch is greatly modified, part of it having concrete containment and other places closely bordered by cleared residential and school yards.

Assad and Roemer also surveyed the lower Walnut Creek drainage, starting at the Guadalupe River junction (Riverview Park) and walking north to West Court Street, one person on either side of the creek because of the narrowness of the course (which is dominated by high banks and abrupt residential backyards except for the park area). A wider area was covered at Riverview Park, mainiy on the western side of the creek mouth. The sewage plant covers most of the eastern 
side of Walnut Creek at the confluence with the Guadalupe River. Riverview Park is well used and the only slightly protected places are on the creek banks where the slope and vegetation hinder walking. These areas were examined closely on the western side of Walnut Creek and on the Guadalupe River, producing no archaeological evidence. Walnut Creek's eastern side was walked below the sewage plant, but a steep embankment extends from the plant to the creek bed covering that section. The remaining survey area north to West Court Street was characterized by a deeper drainage than the upper creek (above West Court), continuous water flow, and steeper banks with occasional nearby residential structures. The only prehistoric evidence found on this lower part of Walnut Creek was on its western bank below Shelby street. Here a few chert flakes were noted amid much historic debris, including foundation rubble and disturbed earth. Also in this vicinity a local resident, George Mead (374 Shelby Street), reported finding a projectile point. No other prehistoric evidence was found along this area of lower Walnut Creek.

There are few general conclusions regarding the prehistoric use of Walnut Creek resulting from this survey. The flakes encountered support the notion that this drainage was at least sporadically utilized in prehistoric times. No clearly definable site was found during the surface survey, which may mean that significant evidence either is not there or at least was not visible. The latter is possible because of the thick vegetation on part of the creek, and modern reuse and natural deposition have probably buried much evidence. Some prehistoric features were undoubtedly washed away or destroyed by historic landmoving activities.

\section{concluding comments}

It is felt that the survey team covered the drainage thoroughly from the Southern Pacific Railroad to the Guadalupe River, with the exception of the smal1 area near the Riverview Cemetery on the eastern side of the Walnut CreekGuadalupe River confluence (access was not permitted in this latter locality). The findings of the surface survey at this time indicate that there is no prehistoric evidence which requires special attention. But it is suggested that when any future vegetation removals or land modifications take place on Walnut creek, a field archaeologist should inspect such modifications, particularly in the vicinity of Riverview Park, and in the thickly vegetated area between Vaughan Avenue and William Street (where lithics were found on the norin bark). 